\title{
The Management of the Water as an Effort to Realize a Green Campus in Universitas Sebelas Maret Surakarta
}

\author{
Prof. Dr. Jamal Wiwoho, S.H., M.Hum. ${ }^{1,}{ }^{*}$, Dr. Suryanto, S.E., M.Si. ${ }^{2}$, Dr. Murtanti, M.T. ${ }^{3}$, \\ Setya Nugraha, S.Si., M.Si. ${ }^{4}$ \\ 1,2,3,4 Universitas Sebelas Maret, Surakarta, Indonesia \\ *corresponding author: rektor@uns.ac.id
}

\section{Article Info}

Received:

15 March 2021

Accepted:

25 May 2021

Published:

1 August 2021

DOI:

Presented in The $6^{\text {th }}$ International (Virtual) Workshop on UI GreenMetric World University Rankings (IWGM 2020)

\begin{abstract}
The main campus of UNS Surakarta, occupies an area of \pm $59,211 \mathrm{Ha}$. At present, the problem faced by UNS is the increasing of narrow green space, so that it increases rain water and lead to runoff. This process has an impact on the increase in flood discharge and the reduction in the supply of rainwater which becomes ground water reserves. In order to realize a Green Campus that supports sustainable development, efforts have been made relating to groundwater and surface water management. A total of 117 infiltration wells and more than 500 biopori infiltration units have been built, which serve to increase shallow groundwater reserves so that it increases rainwater harvesting and soil moisture. Rainwater that cannot be accommodated in infiltration wells is channeled to the lake named Danau UNS which has an area of 1,206 Ha with a maximum water volume of $\pm 7,959 \mathrm{~m}^{3}$, so that it is expected to be able to maintain the shallow ground water balance at the Kentingan UNS Campus. In the future planning, Universitas Sebelas Maret will improve domestic wastewater treatment for other uses, so that there is an efficient use of sustainable clean water.
\end{abstract}

\section{Keyword:}

UNS, Green Campus, Ground Water, Surface Water

\section{Introduction}

Water resources are the gift from the God that is vital for the life and livelihood of all living things. Therefore, its existence in the land of Indonesia needs to be managed wisely, for the welfare and prosperity of all people. Broadly speaking, water distribution consists of $97,25 \%$ occupying seas and oceans; $2.1 \%$ in the form of ice, glaciers and snow; $0.62 \%$ of fresh water that occupies lakes, rivers, soil moisture, and ground water, then the rest is in the atmosphere and brackish water in lakes and straits [1].

The limited availability of water resources on the one hand and the increase of water demand on the other hand lead to the competition among the users of water resources that 
have an impact on the strengthening of the economic value of water. This condition has the potential to cause conflicts of interest between sectors, between regions, and various parties related to water resources. Thus, the regulations are needed in order to protects the interests of the society to meet their daily basic needs and agricultural irrigation.

Ground water which is a natural resource, currently, has an important role in providing water supply for various purposes, thus causing a shift in the value of groundwater itself. Ground water in the past was free goods that could be used freely without limits and did not require monitoring and supervision of their use. In the current era of development which is accompanied by a very rapid increase in groundwater demand, it has changed the value of groundwater into economic goods, meaning that groundwater is traded like other commodities, even in some places ground water has a strategic role.

The use of excessive groundwater continuously causes negative impacts on the environment. It can be seen, if the use of the groundwater is greater than the existing supply into the groundwater aquifer. The impacts that occur when ground water is taken continuously on a large scale are: the damage of aquifer structures by decreasing pore space, the subsidence of the soil surface, and the occurrence of sea water intrusion. While the lack of ground water as the main source of clean water will have a further impact on the decline in sanitation and general health conditions. Especially at this time with the Covid-19 Pandemic that hit Indonesia and the world, the need for clean water increased very sharply, because in the Covid-19 virus spread prevention protocol, it is needed a level of cleanliness of the human limbs, for instance, doing hand washing as often as possible after doing activities.

The role of ground water is increasingly significant; therefore the use of ground water must be based on the balance and sustainability of groundwater itself. In other terms the use of ground water must be environmentally friendly. In order to guarantee the use of groundwater that is environmentally friendly and sustainable, groundwater management is necessary. Based on [2], it explains that the management of water resources is the obligation of the state, community groups, and individuals. As an institution of Higher Education, the Universitas Sebelas Maret (UNS) Surakarta has a program that supports the implementation of Green Campus to create an environmentally friendly campus. The policy has been stated in the Rector of Universitas Sebelas Maret [3].

\section{The Management of the Water}

The management of water resources is carried out based on the strategy of water management implementation with the principle of a balance between conservation efforts and water utilization. The management strategy is implemented as a whole, balanced between conservation efforts and water utilization, integrated in the use of water that is mutually supportive, and involves the role of all water users. The management of water resources is determined on the basis of the Watershed Area for surface water and Groundwater Basin for groundwater management.

Universitas Sebelas Maret Surakarta including Kendil Watershed, where the pattern of surface water flow or drainage network system is divided into two, namely, the eastern and western parts are presented in Figure 1. The division of the drainage system is used as a basis for zoning in water management in the Green Campus, which has become Zone A-G, as shown in Figure 2. 


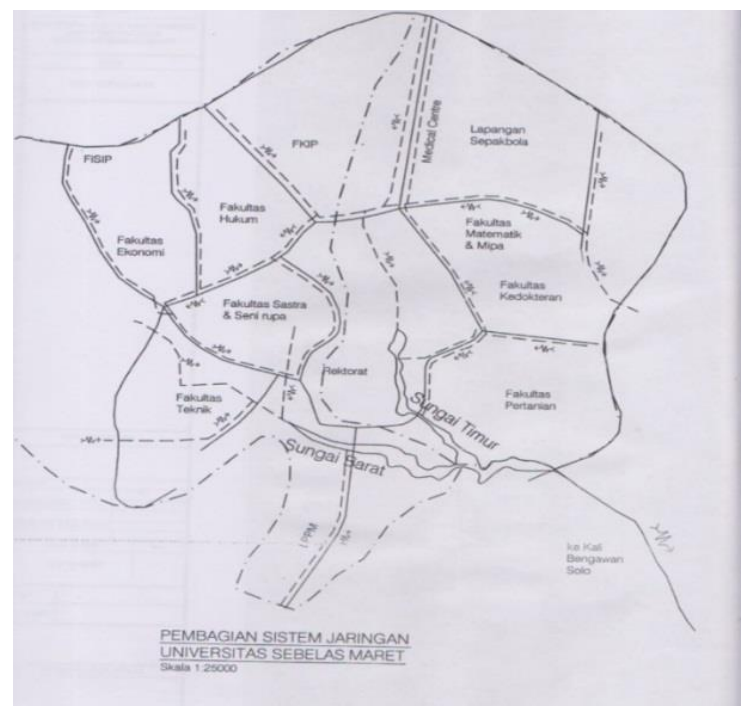

Figure 1. The network system of water surface in UNS

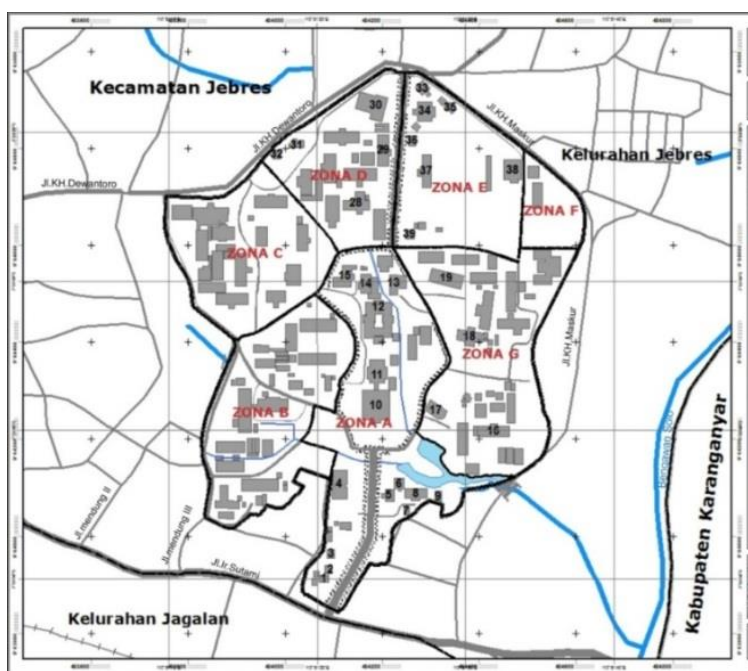

Figure 2. Zoning map in UNS Campus

For the basis of water resource management, data is needed related to the surface flow debit. The debit amount of surface flow that occurred in the area of Universitas Sebelas Maret Campus is presented in Table 1.

Table 1. The Land Cover and the Number of Surface Flow in UNS Surakarta Campus

\begin{tabular}{|c|c|c|c|c|c|c|c|c|c|c|c|}
\hline Zone & $\begin{array}{l}\text { Zone } \\
\text { Area } \\
\left(\mathrm{m}^{2}\right)\end{array}$ & $\begin{array}{c}\text { Building } \\
\text { Area } \\
\left(\mathrm{m}^{2}\right)\end{array}$ & $\begin{array}{l}\text { Road } \\
\left(\mathrm{m}^{2}\right)\end{array}$ & $\begin{array}{c}\text { Vegetati } \\
\text { on Area } \\
\left(\mathrm{m}^{2}\right)\end{array}$ & $\begin{array}{l}\text { River } \\
\left(\mathrm{m}^{2}\right)\end{array}$ & $\begin{array}{l}\text { Lake } \\
\left(\mathrm{m}^{2}\right)\end{array}$ & $\begin{array}{c}\text { Parking } \\
\text { Area and } \\
\text { pavement } \\
\left(\mathrm{m}^{2}\right)\end{array}$ & $\begin{array}{c}\text { C } \\
\text { Weig } \\
\text { hted }\end{array}$ & $\begin{array}{c}\text { Rain } \\
\text { Intensi } \\
\text { ty } \\
\text { (mm/ } \\
\text { month } \\
\text { ) }\end{array}$ & $\begin{array}{c}Q \\
\left(m^{3} /\right. \\
\text { month) }\end{array}$ & $\begin{array}{c}\mathrm{CH} \\
\text { Volume } \\
\left(\mathrm{m}^{3} / \mathrm{mon}\right. \\
\text { th) }\end{array}$ \\
\hline $\begin{array}{r}\text { Zone } \\
\text { A }\end{array}$ & $\begin{array}{l}153 . \\
200\end{array}$ & $\begin{array}{r}24.760, \\
00\end{array}$ & $\begin{array}{r}13.763 \\
, 64\end{array}$ & $\begin{array}{r}52.423 \\
93\end{array}$ & $\begin{array}{r}1.315 \\
, 54\end{array}$ & 0.00 & $\begin{array}{r}58.484,7 \\
9\end{array}$ & $\begin{array}{r}0,65 \\
0\end{array}$ & $\begin{array}{r}170,6 \\
2\end{array}$ & 47,22 & $\begin{array}{r}26.138 \\
984\end{array}$ \\
\hline Zone & 99.6 & 32.052, & 8.467, & 41.348, & 745,3 & 0.00 & $15.486,1$ & 0,62 & 170,6 & 29,44 & 16.993, \\
\hline B & 00 & 00 & 58 & 79 & 3 & & 1 & 3 & 2 & & 752 \\
\hline Zone & 79.6 & 37.573, & 4.000, & 28.061, & 0,00 & 0.00 & $10.282,1$ & 0,69 & 170,6 & 26,21 & 13.581, \\
\hline C & 00 & 00 & 85 & 12 & & & 7 & 4 & 2 & & 352 \\
\hline
\end{tabular}




\begin{tabular}{rcrrrrrrrrrr} 
Zone & 67.8 & 24.612, & 4.837, & 13.806, & 0,00 & 0.00 & $24.353,3$ & 0,76 & 170,6 & 24,73 & 11.568, \\
D & 00 & 00 & 94 & 12 & & & 0 & 9 & 2 & 036 \\
Zone & 74.3 & $3.451,0$ & 4.273, & 43.101, & 0,00 & 0.00 & $23.627,2$ & 0,51 & 170,6 & 18,12 & 12.677, \\
E & 00 & 0 & 58 & 10 & & & 8 & 4 & 2 & 066 \\
Zone & 19.4 & $2.150,0$ & 1.725, & 15.762, & 0,00 & 0.00 & 246,30 & 0,38 & 170,6 & 3,52 & $3.310,0$ \\
F & 00 & 0 & 09 & 63 & & & & 2 & 2 & 28 \\
Zone & 106. & 37.585, & 4.540, & 45.185, & 0,00 & 5.542 & $15.523,6$ & 0,61 & 170,6 & 30,86 & 18.102. \\
G & 100 & 00 & 63 & 54 & &, 52 & 6 & 3 & 2 & 782 \\
Total & $\mathbf{6 0 0 .}$ & $\mathbf{1 6 2 . 1 8}$ & $\mathbf{4 1 . 6 0 9}$ & $\mathbf{2 3 9 . 6 8}$ & $\mathbf{2 . 0 6 0}$ & $\mathbf{5 5 4 2 .}$ & $\mathbf{1 4 7 . 5 1 1}$ & & & 179,90 & 102.37 \\
& $\mathbf{0 0 0}$ & $\mathbf{3 , 0 0}$ & $\mathbf{3 1}$ & $\mathbf{9 , 2 4}$ & $\mathbf{8 7}$ & $\mathbf{5 2}$ & $\mathbf{0 1}$ & & & & 2,00 \\
\hline
\end{tabular}

Source : secondary data

Based on table 1, the surface flow debit that can be used as a supply in managing water resources at Universitas Sebelas Maret is $179.90 \mathrm{~m} 3$ / month. In [3] concerning Management Guidelines of Universitas Sebelas Maret Green Campus, in connection with water resources management, Universitas Sebelas Maret is able to: (1) conduct efficient use of clean water, (2) build infiltration wells, biopores, and other rainwater harvesting structures, (3) use water from waste management to reduce the use of clean water, (4) have wells and rainwater harvesting ponds, and (5) have water reservoirs. This activity aims to manage rainwater that falls into a supplier of ground water reserves, so as to reduce the flow of surface water flow debit.

\subsection{Rain Water Harvesting}

Rain water harvesting is the technique of collecting and storing rainwater into a tank or natural reservoir, or absorbing surface water into aquifers below the surface (before it becomes surface runoff). Rain water harvesting that have been done by Universitas Sebelas Maret Surakarta consist of:

\subsubsection{Biopore Infiltration Holes}

Biopore Infiltration Hole is an alternative and simple technology for rainwater absorption in addition to infiltration wells. Another term of Biopore Infiltration Hole is worm palace, although there are actually not only worms. In addition to water infiltration, biopore is also useful as a domestic waste processor, especially leaf crusters that can be applied on narrow grounds on campus. The number of Biopore Infiltration Hole that have been made from 2015-2019 is more than 500 holes spread across the campus. Biopore Infiltration Hole can be seen in Figure 3.

In the Biopore Infiltration Hole, fauna in the soil will get food from the organic waste and turn the organic waste into compost. Organic waste is put into it to lure animals, such as ants, worms, or termites and create biopore in the form of small tunnels so that the water quickly absorbs, making it useful to fertilize the surrounding soil. 

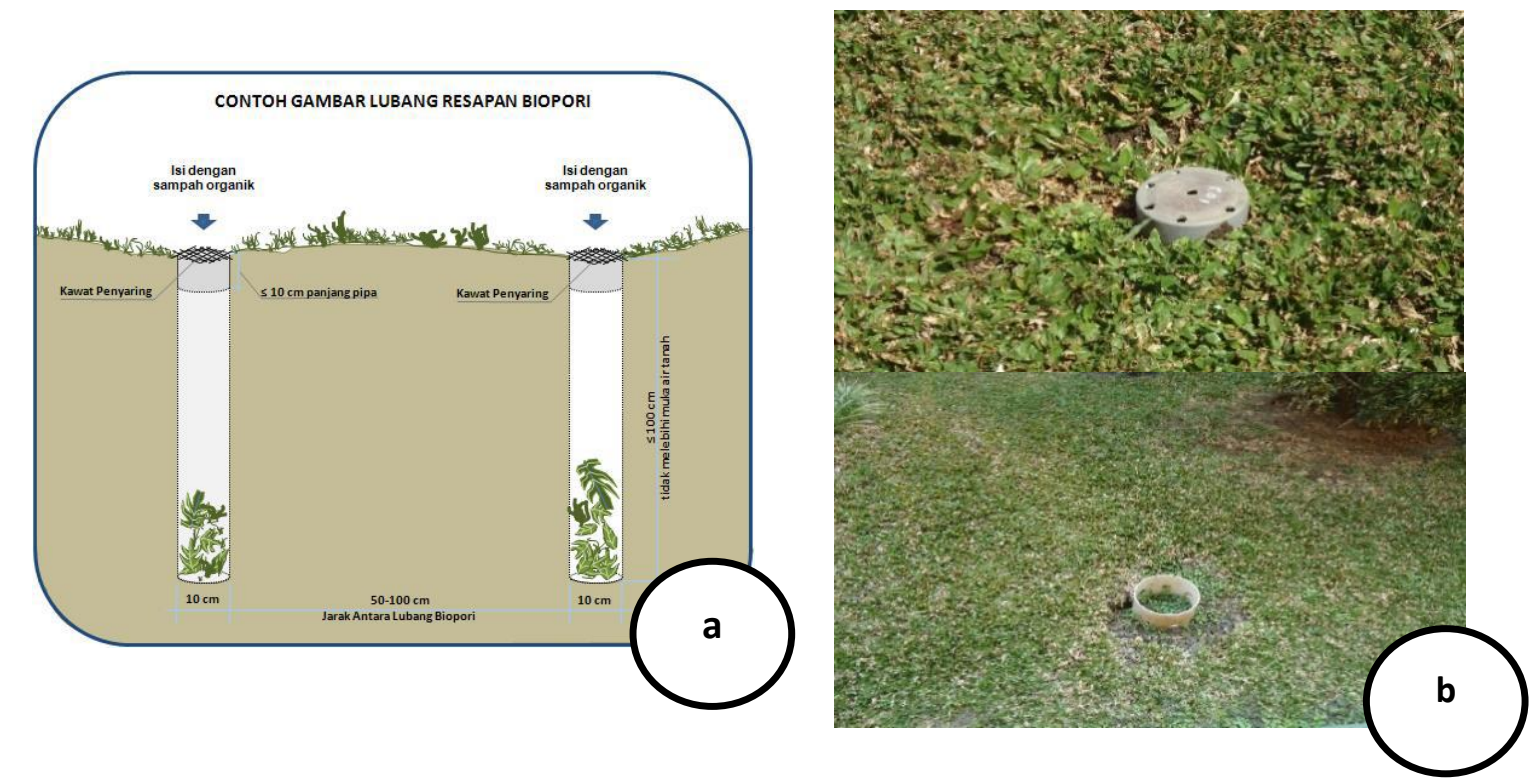

Figure 3. (a) Biopore Infiltration Hole Model ; (b) Biopore Infiltration Hole at UNS

\subsubsection{Infiltration Wells}

Infiltration well is a groundwater and water conservation technique which has the principle of extending the area of absorption by making holes into the soil of a certain size so that surface water flow is reduced optimally. According [5] this infiltration well construction effort is a water conservation technique which is essentially a human effort in maintaining, increasing and developing water use capacity in accordance with its designation.

In this effort, Universitas Sebelas Maret Surakarta has made 117 infiltration wells spread in various locations from the target of 300 infiltration well units. The increasing of the infiltration after the absorption of infiltration wells is $48.88 \%$ of the existing infiltration conditions [6]. Infiltration wells built in UNS can be seen in Figure 4.
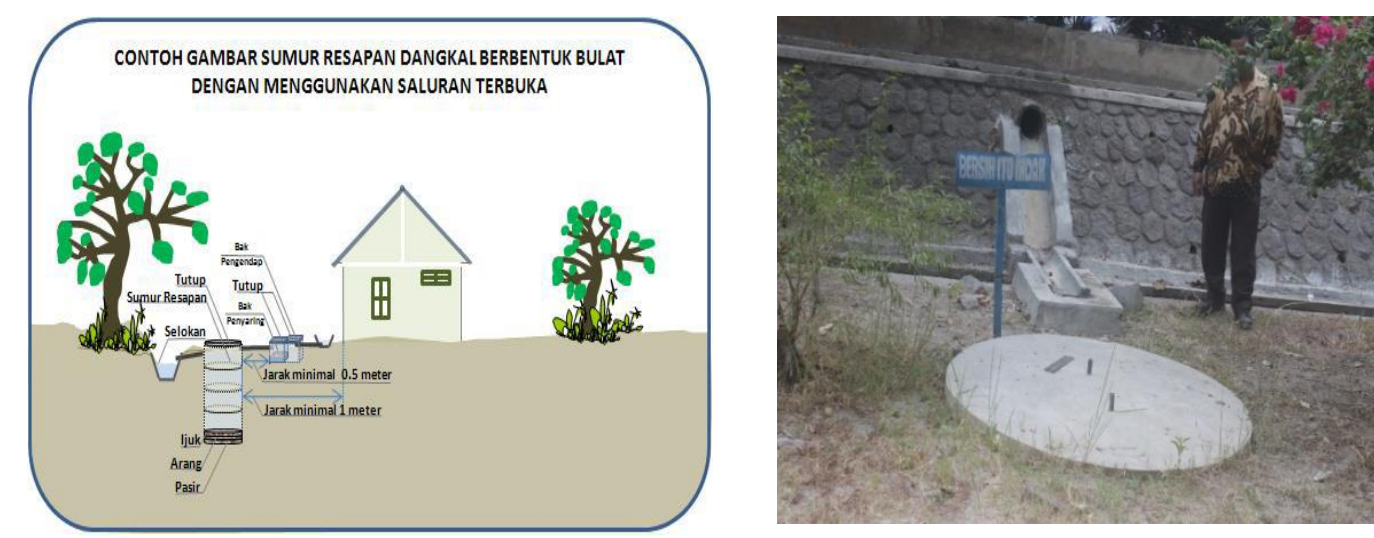

Figure 4. The Model of shallow infiltration wells [4] and infiltration wells at UNS

\subsubsection{Lake}

In conducting surface water management at Universitas Sebelas Maret, in addition to creating biopore infiltration holes and shallow infiltration wells, there is also UNS lake or Danau UNS, which has an area of 1,206 $\mathrm{Ha}$ and the volume of the water of 7,959 $\mathrm{m} 3$. The lake of UNS has several functions including: maintaining water balance on campus, a place 
for student practicum, educational tours, and student learning space. The existence of the Lake of UNS is presented in Figure 5.

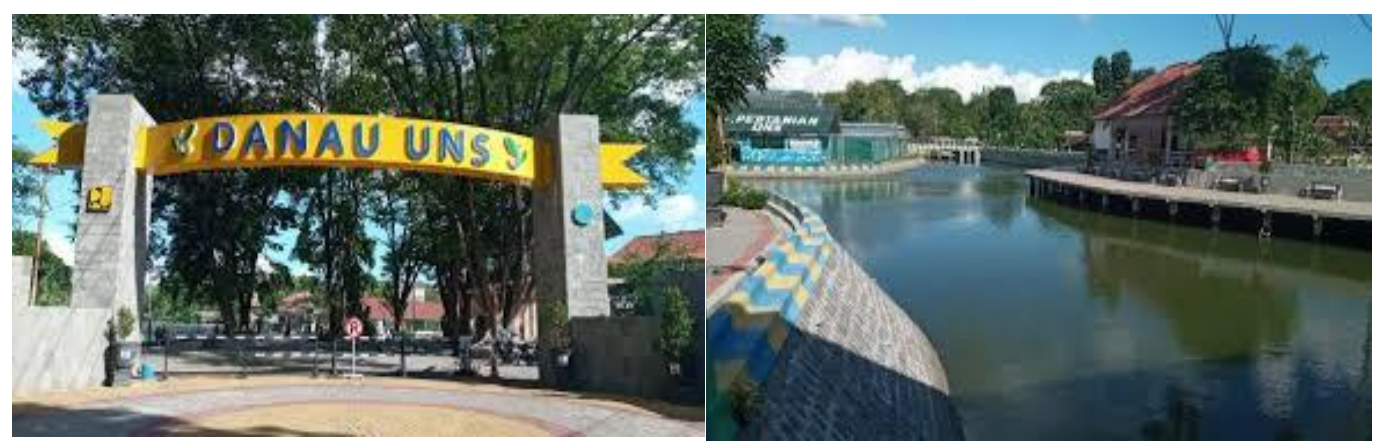

Figure 5. The Lake of UNS

\subsection{The Quality of Surface Water}

The groundwater management at Universitas Sebelas Maret Surakarta aims to maintain the fulfilment of the quantity and quality of the water. In an effort to prevent the groundwater pollution, Wastewater Treatment Plant is one of the installations built by the Directorate General of Cipta Karya, Ministry of Public Works and Public Housing in the area of Universitas Sebelas Maret (UNS) Surakarta. The sanitation of domestic waste with a capacity of 1,290 cubic meters per day was inaugurated on March 9, 2017. Since the existence of the Wastewater Treatment Plant, the wastewater at the Universitas Sebelas Maret does not pollute surface water, thus it gives an impact on the quality of surface water that undergoes an infiltration process at biopore holes, shallow infiltration wells, and the lake of UNS. The existence of Wastewater Treatment Plant can be seen in Figure 6.
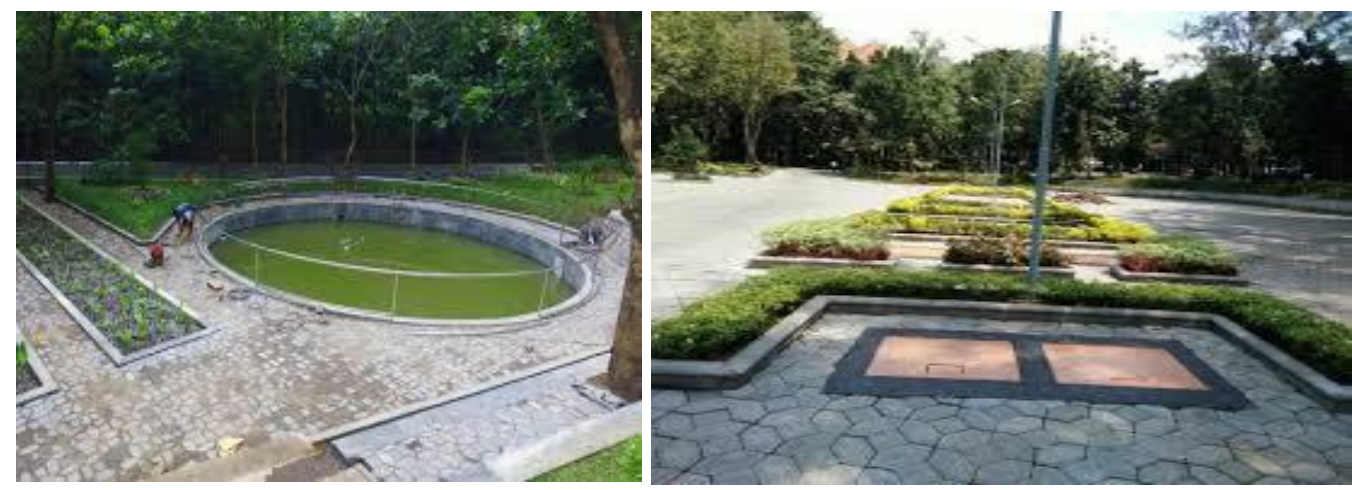

Figure 6. Wastewater Treatment Plant in Universitas Sebelas Maret Surakarta

Based on the results of the study, the main process is found in anaerobic and aerobic biofilter with a residence time of 9.7 hours. Efficiency values on permanganate COD, BOD, and TSS were $49.75 \%, 74.46 \%$, and 52.69\% [7].

\section{Concluding Remark}

The water management as an effort to implement Green Campus is based on the Rector of Universitas Sebelas Maret Regulation Number: 827A / UN27 / KP / 2013 concerning Management Guidelines of Universitas Sebelas Maret Green Campus. It is carried out by: (1) The management to increase the quantity of groundwater is done by creating Biopore Infiltration Hole, Shallow Infiltration Wells, and the Lake of UNS; (2) The management to prevent surface and ground water pollution has been built Wastewater 
Treatment Plant.

\section{References}

1. Wilson,E.M, 1974. Engineering Hydrology. Macmillan Education Ltd

2. Undang-undang RI Nomor 17 tahun 2019 tentang Sumber Daya Air.

3. Peraturan Rektor Universitas Sebelas Maret Nomor : 827A/ UN27/KP/2013 tentang Pedoman Pengelolaan Kampus Ramah Lingkungan (Green Campus) Universitas Sebelas Maret.

4. Peraturan Menteri Negara Lingkungan Hidup Nomor 12 Tahun 2009 tentang Pemanfaatan Air Hujan.

5. Sunjoto, 1989. Teknik Konservasi Air Pada Kawasan Permukiman.Yogyakarta. Universitas Gadjah Mada.

6. Adijaya, S., Sobriyah, Siti Qomariah, 2016. Jurnal Matriks Teknik Sipil Universitas Sebelas Maret-Desember 2016/1086.

7. Pusposari, D.D., 2017. Studi Instalasi Pengolahan Air Limbah (IPAL) Universitas Sebelas Maret Kawasan Jebres Surakarta. Tugas Akhir D3 Teknik Sipil Infrastruktur Perkotaan Universitas Sebelas Maret Surakarta. 